\title{
Fobruary o,
}

\section{FIRE RESISTAICG OF CLAY HOLLOW TALI TILE}

\section{Scope of Presant Rasults}

The fire tasts of hollow tile complated by this Bur aau have Dean of panaIs 4 izat squera. In som of the tasts tha tile ware vuilt within rigid fraris giving estreint on aII adgas, while othars war struction. The tast consisted of buojecting the paneI to a controllad tast fire or one side, with indicated furnace temparatura near $833^{\circ} \mathrm{C}\left(1550^{\circ} \mathrm{F}\right)$ at $30 \mathrm{minut} 3 \mathrm{~s}, 927^{\circ} \mathrm{C}\left(1700^{\circ} \mathrm{F}\right.$ ) at one hour, $1010^{\circ} \mathrm{C}\left(1.550^{\circ} \mathrm{F}\right)$ at 2 houls, $1101^{\circ} \mathrm{O}\left(2000^{\circ} \mathrm{F}\right)$ at 4 hoves and $1177^{\circ} \mathrm{C}$ $\left(2150^{\circ} \mathrm{F}\right)$ at 3 hours.

The strongth and otre physicel piopertios of individual tile

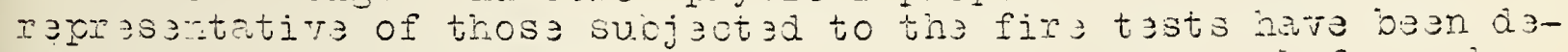

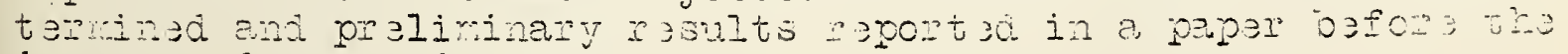
Ameican Caramic Socizt?**

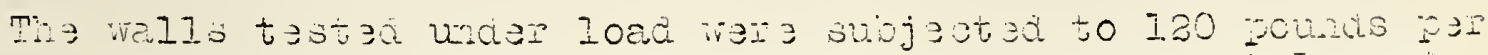
squer irck of groso jearing ar ą for end construction tile and eithar 60 or Eo pounds per squar 3 inch for side corstruction tila. Thəsa lcadingo wara s3lect 3 as being those most comonly used in practice.

A Iurtion serios of fire tasto and fire and weter tosts wherein the test penzls will be 11 feet high and 16 feet wiae will soor be unjertakn, pencing tre conclusion of wich our recommandions should je taken as tentative.

\section{General Fire Test Performance}

As indiceted by toste oi matjrial from 20 sourees representative of the typicai class 3 of $^{\circ}$ ol us us in tile ranuracture, the ability to withotand fire exposure varies videly and is governed oy the class of clat, the wejign of the units, anc the method of build-

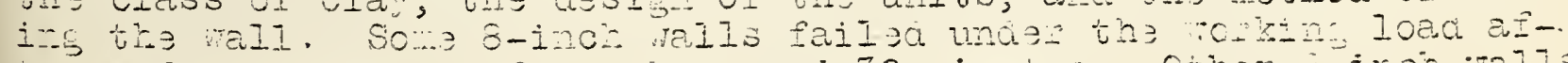

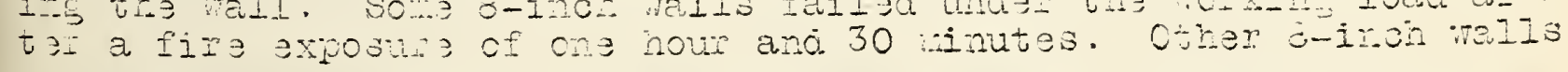
* Strength, Absorption and Frazuing Rajstance of Hollow Building Iile". Jour. Aner. C arario Soo., $r(3)(1924)$. 

Letter Circular 113--2/27/24

Withstood the fire exposura for 6 hours, the limit of tha tast duration. Fxcept with tile from one clay, all panels built of load baaring tile of stardard weight were able to support tha full vorking load throughout tha 6-hour test.

The fire damage varies greatly in amount depending mainly on the kind of clay from which tha tile is made and tha design of tha units, soma tila showing little or no effacts after 6hour fire exposur 3 , othars suffering mat erial damage after relativaly short fires. That minerals or minaral combinations in tha clay are responsible for the difference in fire effects not?d, is not as yət dəfinitəIy known, although indications are that minor constituents recurring consistently with given typas of clays and acting as fluxes are importent factors. The extent of the damage and its influence on the strength of the wall is governed in a degrea by tha number of ceils through the thickness of the wall, dacreasing as tha number of cells is incr aased, the darage whero pr ssent being generally confined to the shell or cell on tha fire side. With two unit la-inch walls built of 4-inch and 8-inch tile, the darage is confinad to portions of tha exposed unit. The susceptibility to damage also decreases with incr zase in shell thickness. As would be axpectad, tha temperatures on the unexposed face after given fire exposures on the opposit f face also are lower where the thicker jhells or greater number of calls are present. ITo difference in fire rasistance was noted between and construction and side construction tile having comparable shell thicknass and number of cells, this statement also applying to such tile of spacial disign as were tasted.

The following table gives the averaga time required to r each temperatures of $150^{\circ} \mathrm{C}\left(302^{\circ} \mathrm{F}\right)$ and $250^{\circ} \mathrm{C}\left(482^{\circ} \mathrm{F}\right)$ on the unaxposad side of unplasterad walls. Tha lower temperature was chosen bacause of the common use of $300^{\circ} \mathrm{F}$ as a limit of parmissicle temperatura for tha unaxposad side of partitions in specifications for fire tasts of such construction. Wille this tamparatura is below the igaition point of oluinary combustible mat hazardous materials like celiuloid, matches, and a number of chemical compouncis, it is probabiy not too high as a limit for ganeral tomperatures on the uncover ad sulface, consiaering that higher tomperatures ar a likely to preveil at cracks and open joints and under combustible atirial that may be piled against the wall. The higher temperatur, $250^{\circ} \mathrm{C}$, can be taken as the actual border temperature that will produce ignition of orcinary combustible matorials under tha conditions obtaining in building fires. 



\begin{tabular}{|c|c|c|c|}
\hline $\begin{array}{c}\text { Thickness } \\
\text { of } \\
\text { Wail } \\
\text { in } \\
\text { inches }\end{array}$ & $\begin{array}{l}\text { Kind of Unit } \\
\text { or } \\
\text { Construction }\end{array}$ & \multicolumn{2}{|c|}{$\begin{array}{l}\text { Time required to reach given tempara- } \\
\text { tures on the unexposed side }\end{array}$} \\
\hline 8 & Partition tile & $1 \mathrm{hr}, 15 \mathrm{~min}$. & $2 \mathrm{hr} ., 15 \mathrm{~min}$. \\
\hline 8 & $\begin{array}{l}\text { Load baaring } \\
\text { tile of stand- } \\
\text { ard wight }\end{array}$ & I hr., 45 min. & $3 \mathrm{hr}, 15 \mathrm{~min}$. \\
\hline 12 & $\begin{array}{l}\text { Singla unit, } \\
\text { la-inch } 8-c e 11 \\
\text { load-b aning } \\
\text { tile }\end{array}$ & $3 \mathrm{hr} .15 \mathrm{~min}$. & $5 \mathrm{nr} ., 0 \mathrm{~min}$. \\
\hline 12 & $\begin{array}{l}\text { Two unit } 8- \\
\text { inch and } 1- \\
\text { inch load- } \\
\text { b aaring tile }\end{array}$ & $4 \mathrm{hr} ., 15 \mathrm{~min}$. & $\begin{array}{l}\text { Not reached in } \\
\text { six hours. }\end{array}$ \\
\hline
\end{tabular}

The time required to reach these temperatures varias with the thicknass of the wall, the dəsign of the unit, and the method of construction. Grpsum and Portland cement plasters, or mixtures of thos? plast ors with lime plaster, such as will remain in place during the fire tast will incraase tha times required to obtain given temporatuies by one-half hour to one hour or over, the gr aat or incremants baing incident with the heaviar valls.

The above time periods should not ba takjn as the safe fire resistance periods, in deriving which the results of the tasts must be discountad to allow for the graatsr rang? in quality of mat $3 i a l$ ana workanship obtaining in builaing construction as compar ad with that incident with the relatively fow duplications of test spacimans possiole to irtroduce. As previously indicated the results are also limitod by the size of the tast panel, walls of a building story in height baing subject to grater daflaction than the 4-foot test panjI, which has a baring on the ability of the rall to sustain load under fir these limitations it appears piobable that 8-inch unplastered walis of load bearing hol low tila will satisfactorily hold back fires in intensity and duration equivalent to the first hour of 

the fire test exposur 3 and tha l2-inch walls, fir 3 equal to the first $a$ or $21 / 2$ hours. This would make 8 -inch walls adequate in residence, office and institutiona.I occupancies wher no considerable accumulation of combustible matorial is present. For the mora savere exposures in thase occupancias as also for those involving marchandizing and manufacturing with moderate amounts of combustible materials, the 13-inch wall will apparentIy ba adequate. Walis haavi or than la inchas would oz noeded for the more a evere fire conjitions incicent with mercantile, manufacturing, warohouse and storaga establishments. Suitable plastər coatings would ada matorialiy to the rasistances above outIinza.

Tha abova conclusions ref er particularly to baaring partitions and party and fire vells in fire resistive buildings. In othar buildings and in all cases where combustible or non-fire rasistiva members ar a framad into tha wall, they should not project more than $3 \mathrm{l} / 2$ inches into tre wall for 8 and 12 inch valls, and the ands in the wall should hava not less than 4 inches of solid ratericil above, below and between them, if the full iire resigtance of tir wall is to ba developed.

The above conclusions apply particularly to intarior axposures. As it refers to $3 x p 0$ sur 3 s from the outsida, tha fir effects on neighboring detachad builuings from tha burning of

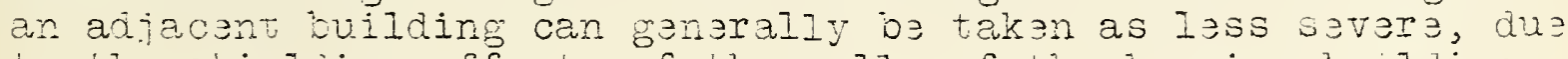
to the shielding effects of the walls of the burning building, anc İss opportunity for high temperatures to build up in the unconfined space batween them.

The above is submitted for your information and is not intended for publication. 
